EMBRYARIDDLE
Aeronautical University

SCHOLARLY COMMONS
International Journal of Aviation, Aeronautics, and Aerospace

\title{
An integrated method for airline company supplier selection based on the entropy and vikor methods: a real case study
}

\author{
Naimeh Borjalilu \\ University of Tehran, borjalilu@ut.ac.ir \\ Zeinab Sazvar \\ University of Tehran, sazvar@ut.ac.ir \\ Sina Nayeri \\ University of Tehran, sina.nayeri@ut.ac.ir
}

Follow this and additional works at: https://commons.erau.edu/ijaaa

\section{Scholarly Commons Citation}

Borjalilu, N., Sazvar, Z., \& Nayeri, S. (2021). An integrated method for airline company supplier selection based on the entropy and vikor methods: a real case study. International Journal of Aviation, Aeronautics, and Aerospace, 8(4). https://doi.org/10.15394/ijaaa.2021.1626

This Article is brought to you for free and open access by the Journals at Scholarly Commons. It has been accepted for inclusion in International Journal of Aviation, Aeronautics, and Aerospace by an authorized administrator of Scholarly Commons. For more information, please contact commons@erau.edu. 
Supply chain management plays a crucial role in today's industry (Ghosh et al., 2019). Supplier selection is one of the main purchasing researched scopes with conceptual, empirical, and modeling streams methodologies (Feng et al., 2012). Supplier selection is a very essential aspect in supply chain management (SCM) and firms spend a minimum of $60 \%$ of their total sales on purchasing items and being one of the most vital decision-making issues for the organization (Kumar et al., 2018). In addition, a large number of factors, indexes, and criteria should be analyzed through supply chain experts by considering external and internal variables. Supply chain developers should be optimized system performance as well the system of supplier evaluation considering economic, social, governmental, and environmental aspects (Yazdani et al., 2016). Collaboration with selected suppliers is one of the chief operations in SCM. Flight operations is critical activities in an airline and their outputs are a direct impact on safety consequence. Therefore, the quality of supplier's products and services has the main role in their process (ICAO, 2018). Stability in the procurement process in airlines is a strategic issue in recent decades. Suppliers should deliver the required amount of good quality materials and raw materials on time. Decision-making can be used to select the most optimum and suitable choice among numerous alternatives (Uzan, 2020). This study investigated developing a hybrid decision-making framework based on the Entropy and VIKOR methods to investigate the supplier selection problem for an airline. To do this, at the first step, the most important criteria and sub-criteria are extracted based on the literature review and the experts' opinions. In the next step, the weights of criteria and sub-criteria are measured by applying the Entropy method. Eventually, the potential suppliers are ranked using the VIKOR approach. The main advantages of employing the integrated Entropy-Vikor are (i) its ability to avoid the subjectivity of weight selection, (ii) its ability to fully utilize the sample data to obtain the importance weight of each criterion, and (iii) its ability to consider group utility in ranking alternatives (Petrović et al., 2019). In general, this paper addresses the following objectives:

- Identifying the main criteria for the supplier's evaluation and selection for airline in the aviation industry (flight operations).

- $\quad$ Developing a hybrid decision-making framework by a combination of the Entropy and VIKOR methods.

Selecting the best supplier in flight operations.

The rest of the paper is organized throughout several sections. The second section provides a review of the previous studies of supplier selection and the importance of a complete, sustainable supply chain. The third section presents the methodology, a detailed algorithm for the new method. A description of a case study with all the necessary elements of the MCDM method is presented in the fourth section and the results with detailed explanations are presented. The paper ends with conclusions with guidelines for future research. 


\section{Literature Review}

The evaluation and selection of an optimal, efficient, and reliable supplier are becoming more and more essential for companies in today's logistics and supply chain management (Feng et al., 2011).

Flight operations is critical activities in airline and their outputs are a direct impact on safety consequence. Therefore, the quality of supplier's product and services play the main role in their process. In this section, a series of literature surveys have been studied to identify the criteria and decision methods for the performance of supplier's evaluation. The supplier selection and evaluation process is a multi-criteria decision-making problem in which both qualitative and quantitative considerations are involved. In the latest literature survey by Ho et al. (2010), the mathematical programming models were grouped into five categories (linear programming, integer linear programming, integer non-linear programming, goal programming, and multi-objective programming) to evaluate supplier's performance.

Furthermore, Feng et al. (2011) developed a model and algorithm for supplier selection in multi-service outsourcing. A multi-objective $0-1$ programming model involving three objectives (collaborative utility, service outsourcing cost, and service waiting time) was built for selecting a pool of desired suppliers for the provision of different SPEs.

An integrated approach of clustering and multi-criteria decision-making methods also were modeled by Azadnia et al. (2012) to solve the sustainable supplier selection problems.

Yazdani et al. (2016) delivered an integrated model of supplier selection problems using SWARA, QFD, and a new MCDM tool called WASPAS. This research considered customer attitudes in the process of supplier evaluation.

Furthermore, a survey was conducted by Ghosh et al. (2019) which used the fuzzy TOPSIS method to select a supplier for knit fabrics of an apparel manufacturer considering multiple criteria.

In another research, Sar1 et al. (2016) developed an alternative solution strategy to select suppliers under uncertain conditions. In the mentioned study, four main criteria were used for suppliers' performance measurement then the performances of 15 suppliers of a food manufacturing company were evaluated using grey relational analysis, and the best supplier was selected based on four main criteria and fifteen sub-criteria.

Cheng et al. (2017) developed a hybrid DEA-Adaboost model to establish the hybrid model for supplier selection. From a complete set of criteria for the iron and steel industry, five criteria were considered by Kumar et al. (2018) to evaluate supplier selection. This study dealt with the uncertain issue of supplier selection using an integrated TOPSIS model for multi-criteria decision-making (MCDM). 
Moreover, a decision framework under a mixed information environment was developed by $\mathrm{Wu}$ et al. (2019). Under the consideration of fuzzy logic importance and decision-making contribution, an approach combining the analytic hierarchy process and the entropy theory was used to compute index importance.

In addition, Shendryk et al. (2019) studied the optimal goods supplier selection based on the AliExpress trading platform under multicriteria conditions regarding the Analytic hierarchy process method.

Petrović et al. (2019) demonstrated the applicability of three fuzzy MCDM approaches (Fuzzy SWARA and Fuzzy TOPSIS, Fuzzy SWARA and Fuzzy WASPAS, Fuzzy SWARA and Fuzzy ARAS) in the selection of suppliers of mechanical components with main criteria.

In another study, multi-criteria decision-making techniques (DEMATEL, MOORA, and ARAS techniques) in the airline information technologies department were developed by Uzan (2020) to reveal how software companies are selected.

Stević et al. (2020) used a new measurement of alternatives and ranking according to the compromise Solution (MARCOS) method for a sustainable supplier selection in the healthcare industry (in a polyclinic) to identify and determine the possibility to consider a large set of criteria and alternatives while maintaining the stability of the method.

Ho et al. (2020) reviewed the literature of the multi-criteria decisionmaking approaches for supplier evaluation and selection. The result showed that the multi-criteria decision-making approaches were better than the traditional cost-based approach. Moreover, price or cost was not the most widely adopted criterion. Instead, the most popular criterion used for evaluating the performance of suppliers was quality, followed by delivery, price or cost, and so on.

A multi-stage hierarchical fuzzy index-based approach with decisionmakers also was empowered by Hendiani et al. (2020) to select the most sustainable supplier based on sustainability triple bottom line criteria. Besides, a new fuzzy extension for the best-worst method was developed considering trapezoidal fuzzy membership functions that can cover uncertainty under imprecise environments. Marzouk et al. (2021) in their researches used a MultiCriteria Decision Making (MCDM) model based on social indicators of sustainability. Hashmi et al. (2021) studied the supplier selection problem (SSP) concerning the carbon footprint associated with the activities of each supplier. Some parameters in the proposed model were considered to be uncertain values. The proposed multi-objective supplier selection problem with an uncertain parameter was solved using a fuzzy concept-based goal programming approach.

According to the literature review, all criteria which evaluate the supplier in the aviation industry are studied. Table 1 shows a brief review of studies for 
supplier selection in the relevant industry and also the suggested criteria which will be used in this paper. In accordance with the necessity of having an integrated model to assess airlines supplier's performance with a hybrid decision-making framework, there are some gaps in the modeling of the researches that have been carried out and described above. These gaps were the motivation to develop a new model for supplier assessment.

- Firstly, there are not any integrated studies for identifying all characteristics which impact Flight operations performance.

- Secondly, consideration of each supplier's performance without comparison with others may cause the overestimation or underestimation of supplier's selection for top management to consider in-flight operations.

- Thirdly, lack of a systematic evaluation process for categorizing suppliers based on flight operations characteristics.

- Fourthly, without criteria prioritizing, the equal effect of each criterion to measure supplier's performance is a matter of difficulty.

In this study, for the first time, the critical factors and criteria are developed in the aviation industry, especially operations scope in an airline. Accordingly, by using expert judgment, considering proposed criteria, and proper decision making, the best supplier is chosen. The airline supplier's assessment through expert judgment and integrated criteria are the new approaches that are developed in this paper. Therefore, along with reviewing and classification of the proposed criteria, prioritizing parameters influencing the mathematical model is introduced and finally a model will be presented through case study implementation.

\section{Table 1}

\section{Review of Studies for Supplier Selection}

\begin{tabular}{|c|c|c|c|}
\hline $\begin{array}{c}\text { Methodologies / } \\
\text { Techniques used }\end{array}$ & Criteria & $\begin{array}{c}\text { Researcher } \\
\text { (Year) }\end{array}$ & $\begin{array}{c}\text { Aviation } \\
\text { Industry }\end{array}$ \\
\hline $\begin{array}{c}\text { A Multi-Objective } \\
\text { Problem: Fuzzy } \\
\text { Concept-Based Goal } \\
\text { Programming } \\
\text { Approach }\end{array}$ & $\begin{array}{l}\text { Minimization of the total cost } \\
\text { involved in the process } \\
\circ \quad \text { Minimization of the total carbon } \\
\text { emission in the whole process } \\
\text { Minimization of the late } \\
\text { delivered items } \\
0 \quad \text { Minimization of the total } \\
\text { rejected items respectively }\end{array}$ & $\begin{array}{l}\text { Hashmi et } \\
\text { al. (2021) }\end{array}$ & \\
\hline $\begin{array}{c}\text { DEMATEL, } \\
\text { MOORA, and ARAS } \\
\text { techniques }\end{array}$ & $\begin{array}{l}\text { Institutional competence level: } \\
\text { domain expertise, references } \\
\text { Project solution: satisfaction of } \\
\text { requirements, the competence of the } \\
\text { project team, solution summary, draft }\end{array}$ & $\begin{array}{c}\text { Uzan, S. B. } \\
\text { (2020) }\end{array}$ & \\
\hline
\end{tabular}




\begin{tabular}{|c|c|c|c|}
\hline $\begin{array}{l}\text { Methodologies / } \\
\text { Techniques used }\end{array}$ & Criteria & $\begin{array}{l}\text { Researcher } \\
\quad \text { (Year) }\end{array}$ & $\begin{array}{l}\text { Aviation } \\
\text { Industry }\end{array}$ \\
\hline & $\begin{array}{l}\text { project plan, hosting solution, ticket sales } \\
\text { prototype }\end{array}$ & & \\
\hline $\begin{array}{c}\text { Multi-stage } \\
\text { hierarchical fuzzy } \\
\text { index-based } \\
\text { approach }\end{array}$ & $\begin{array}{l}\text { The most sustainable supplier based on } \\
\text { sustainability triple bottom line criteria }\end{array}$ & $\begin{array}{l}\text { Hendiani et } \\
\text { al. (2020) }\end{array}$ & \\
\hline MARCOS & $\begin{array}{l}\text { Economic criterion, price, quality, } \\
\text { assortment width, on-time delivery, } \\
\text { innovativeness, organization and } \\
\text { management, reliability, social criterion } \\
\text { reputation, work safety, and labor health, } \\
\text { information disclosure, the interests and } \\
\text { rights of employees, disciplinary and } \\
\text { security practices, training, respect for the } \\
\text { policies, environmental criterion, } \\
\text { environmental competencies, } \\
\text { environmental management system, } \\
\text { recycling, pollution control, green R\&D, } \\
\text { green products, number of obtained ISO } \\
\text { standards }\end{array}$ & $\begin{array}{l}\text { Stević et al. } \\
\quad(2020)\end{array}$ & \\
\hline $\begin{array}{l}\text { Fuzzy TOPSIS- } \\
\text { ANFIS fuzzy logic }\end{array}$ & $\begin{array}{ll}\circ & \text { Quality } \\
\circ & \text { Pricing } \\
\circ & \text { Quick Responsiveness } \\
\circ & \text { Chain Management } \\
\circ & \text { Production Capacity } \\
\circ & \text { Professional \& Financial } \\
\text { Competence } \\
\circ & \text { Chain Motivation } \\
\end{array}$ & $\begin{array}{l}\text { Ghosh et al. } \\
\text { (2019) }\end{array}$ & \\
\hline $\begin{array}{l}\text { Analytic Hierarchy } \\
\text { Process (AHP), } \\
\text { TOPSIS }\end{array}$ & $\begin{array}{l}\text { Social strategies, health, and safety, } \\
\text { stakeholder involvement, social } \\
\text { management commitment, social code of } \\
\text { conduct, donation for sustainable projects, } \\
\text { occupational health and safety } \\
\text { management system, safety practices, the } \\
\text { annual number of accidents, the rights of } \\
\text { stakeholders, stakeholder's relations, } \\
\text { training of employees, child labor, equity, } \\
\text { gender diversity. }\end{array}$ & $\begin{array}{l}\text { Marzouk et } \\
\text { al. (2019) }\end{array}$ & \\
\hline $\begin{array}{l}\text { Analytic Hierarchy } \\
\text { Process and The } \\
\text { Entropy Theory }\end{array}$ & $\begin{array}{ll}- & \text { Product Quality } \\
\circ & \text { Conversion efficiency }\end{array}$ & $\begin{array}{l}\text { Wu et al. } \\
(2019) \text {. }\end{array}$ & \\
\hline
\end{tabular}




\begin{tabular}{|c|c|c|c|}
\hline $\begin{array}{l}\text { Methodologies / } \\
\text { Techniques used }\end{array}$ & Criteria & $\begin{array}{l}\text { Researcher } \\
\text { (Year) }\end{array}$ & $\begin{array}{l}\text { Aviation } \\
\text { Industry }\end{array}$ \\
\hline & $\begin{array}{ll} & \text { Degradation rate } \\
\circ & \text { Environmental adaptability } \\
\circ & \text { Product defect rate } \\
- & \text { Service } \\
\circ & \text { Timely supply } \\
\circ & \text { Quality assurance period } \\
\circ & \text { After-sale services } \\
& \\
- & \text { Cost } \\
\circ & \text { Purchase prices } \\
\circ & \text { O \& M costs } \\
& \\
- & \text { Reliability } \\
\circ & \text { Environmental awareness } \\
\circ & \text { R \& D capability } \\
\circ & \text { Credit ND reputation }\end{array}$ & & \\
\hline $\begin{array}{l}\text { Integrated TOPSIS } \\
\text { model for multi- } \\
\text { criteria decision } \\
\text { making(MCDM) }\end{array}$ & $\begin{array}{l}\text { Cost } \\
\text { Delivery capabilities } \\
\text { Quality of product } \\
\text { Performance } \\
\text { Reputation }\end{array}$ & $\begin{array}{l}\text { Kumar et } \\
\text { al. (2018) }\end{array}$ & \\
\hline $\begin{array}{l}\text { AliExpress trading } \\
\text { platform under } \\
\text { multicriteria } \\
\text { conditions regarding } \\
\text { the Analytic } \\
\text { hierarchy process } \\
\text { method }\end{array}$ & $\begin{array}{l}\circ \\
\text { and communication } \\
\circ \quad \text { Sending Speed } \\
\circ \quad \text { Neutral and negative feedback, } \\
\circ \\
\text { positive feedback for the month and } \\
\text { positive feedback for } 6 \text { months } \\
\circ \quad \text { Number of sales per month and } \\
\text { number of sales in } 6 \text { months }\end{array}$ & $\begin{array}{l}\text { Shendryk et } \\
\text { al. (2018) }\end{array}$ & \\
\hline $\begin{array}{l}\text { A hybrid DEA- } \\
\text { Adaboost model }\end{array}$ & $\begin{array}{l}\circ \quad \text { Economic criteria are technology } \\
\text { capability (TC) and financial capability } \\
(\mathrm{FC}) \text {. } \\
\circ \quad \text { The environmental criterion is } \\
\text { environmental cost (EC). } \\
\circ \quad \text { Social criterion is the cost of } \\
\text { work safety and labor health }\end{array}$ & $\begin{array}{l}\text { Cheng et al. } \\
\text { (2017) }\end{array}$ & \\
\hline
\end{tabular}




\begin{tabular}{|c|c|c|c|}
\hline $\begin{array}{l}\text { Methodologies / } \\
\text { Techniques used }\end{array}$ & Criteria & $\begin{array}{c}\text { Researcher } \\
\text { (Year) }\end{array}$ & $\begin{array}{l}\text { Aviation } \\
\text { Industry }\end{array}$ \\
\hline $\begin{array}{c}\text { Grey relational } \\
\text { analysis }\end{array}$ & $\begin{array}{l}\circ \quad \text { Delivery (on-time delivery, } \\
\text { delivery appropriate to the order quantity, } \\
\text { ability to supply urgent orders. } \\
0 \quad \text { Quality (Ratio of rejected } \\
\text { products, quality improvement } \\
\text { performance, having necessary } \\
\text { documentation, food safety inspection } \\
\text { score, customer satisfaction, technical } \\
\text { support) } \\
\text { capacity, innovation proposals, preventive } \\
\text { and corrective activities) } \\
\quad \text { Price: (Best price, cost-reducing } \\
\text { activities) }\end{array}$ & $\begin{array}{l}\text { Sar1 et al. } \\
\text { (2016) }\end{array}$ & \\
\hline $\begin{array}{c}\text { A multi-objective } \\
\text { problem: } \\
\text { a multi-objective } \\
\text { algorithm based on } \\
\text { Tabu search }\end{array}$ & $\begin{array}{l}\text { Collaborative utility } \\
\text { Service outsourcing cost } \\
\text { Service waiting time }\end{array}$ & $\begin{array}{l}\text { Feng et al. } \\
\quad(2016)\end{array}$ & - \\
\hline $\begin{array}{c}\text { Fuzzy SWARA + } \\
\text { Fuzzy TOPSIS, } \\
\text { Fuzzy SWARA + } \\
\text { Fuzzy WASPAS, and } \\
\text { Fuzzy SWARA + } \\
\text { Fuzzy ARAS }\end{array}$ & $\begin{array}{l}\text { Product price } \\
\text { Transportation costs } \\
\text { Delivery time } \\
\text { Company rating } \\
\text { Established cooperation }\end{array}$ & $\begin{array}{l}\text { Petrović et } \\
\text { al. (2016) }\end{array}$ & - \\
\hline $\begin{array}{l}\text { SWARA, QFD, and a } \\
\text { new MCDM tool } \\
\text { called WASPAS }\end{array}$ & $\begin{array}{ll}\circ & \text { Quality adoption } \\
\circ & \text { Price } \\
\circ & \text { Energy consumption } \\
\circ & \text { Delivery speed } \\
\circ & \text { Green design } \\
\circ & \text { Re-use re-cycle rates } \\
\circ & \text { Production planning }\end{array}$ & $\begin{array}{l}\text { Yazdani et } \\
\text { al. (2016) }\end{array}$ & \\
\hline
\end{tabular}




\begin{tabular}{|c|c|c|c|}
\hline $\begin{array}{l}\text { Methodologies / } \\
\text { Techniques used }\end{array}$ & Criteria & $\begin{array}{l}\text { Researcher } \\
\text { (Year) }\end{array}$ & $\begin{array}{l}\text { Aviation } \\
\text { Industry }\end{array}$ \\
\hline $\begin{array}{c}\text { Clustering And } \\
\text { Multi-Criteria } \\
\text { Decision Making } \\
\text { Methods }\end{array}$ & $\begin{array}{ll}- & \text { Economic: } \\
\circ & \text { Cost } \\
\circ & \text { Quality } \\
\circ & \text { Delivery } \\
& \\
- & \text { Social: } \\
\circ & \text { Occupational Health and Safety } \\
\text { Management Systems } \\
\circ & \text { The rights of stakeholders } \\
- & \text { Environmental: } \\
\circ & \text { Pollution } \\
\circ & \text { Environment-friendly product } \\
\text { design } & \\
\circ & \text { Environmental management } \\
\text { system } & \end{array}$ & $\begin{array}{l}\text { Azadnia et } \\
\text { al. (2012) }\end{array}$ & \\
\hline DEA, AHP-GP & $\begin{array}{l}\text { Quality, followed by delivery, price, or } \\
\text { cost }\end{array}$ & $\begin{array}{l}\text { Ho et al. } \\
\text { (2010) }\end{array}$ & \\
\hline
\end{tabular}

\section{Method}

As mentioned in previous sections, the main contribution of this paper is considering the concept of MCDM in the quantitative model and introduce and apply the new supplier selection and assessment method through main criteria to design a selection method in alignment with the whole supply chain profitability where the SC earns more profit and enhances its productivity in the aviation industry.

This section presents the methodology for selecting a sustainable supplier consisting of three phases as shown in Figure 1. Sustainable supplier selection in aviation industries has been performed throughout three phases:

- $\quad$ In the first phase, the formation of an expert team is completed and a set of alternatives is defined, i.e. a set of potential suppliers, which represents the formation of a multi-criteria model.

After setting the problem, in the second phase, the weight coefficients for all levels of the hierarchical structure are calculated. The first stage was to acquire the weights and rankings of criteria using the Entropy method and the second stage was to evaluate their performance using the VIKOR method.

VIKOR (by compromising solutions) is one of the proper decision-making methods that develop stable decision-making performance by using adaptive solution theory (Opricovic \& Tzeng, 2004). The maximum productivity of the 
"majority" group and the minimum individual regret of the "opposite" group and the agreed solution are the main VIKOR method advantage that can be easily gained by decision-makers. The Entropy weights method (EWM) calculates the objective weights of the attributes/ responses using probability theory for uncertain information (Entropy) computation. Moreover, the entropy weight method can fully use the sample data for the importance weight calculation of each criterion. The main advantage of integrated ENTROPY-VIKOR implementation is to evaluate, compare and rank the decision alternatives because it can avoid the subjectivity of weight selection (Petrović et al., 2019). Figure 1 shows a detailed description of the all steps which are done for supplier selection and evaluation in this paper.

\section{Figure 1}

Methodology for the Supplier Selection Process

\begin{tabular}{|c|c|}
\hline $\begin{array}{c}\text { Phase } 1 \\
\text { Research }\end{array}$ & $\begin{array}{l}\text { - Forming an expert group and defining a set of alternatives } \\
\text { (suppliers) } \\
\text { - Defining a set of criteria/sub-criteria for alternatives } \\
\text { evaluation }\end{array}$ \\
\hline $\begin{array}{l}\text { Phas2 : } \\
\text { Determining } \\
\text { weights of }\end{array}$ & $\begin{array}{l}\text {-Grouping of criteria/sub-criteria and ranking within the expert } \\
\text { groups } \\
\text { - Expert pairwise comparison of criteria and defining the restrictions } \\
\text { of a nonlinear model } \\
\text { - Calculating the final values of the weights of criteria }\end{array}$ \\
\hline $\begin{array}{l}\text { Phase 3: } \\
\text { Suppliers }\end{array}$ & $\begin{array}{l}\text { - Forming expert decision-making matrices } \\
\text { - Normalization of an initial decision-making matrix and a weighted } \\
\text { matrix formation } \\
\text { - Forming a ranking list of suppliers }\end{array}$ \\
\hline
\end{tabular}

\section{Measurement of Alternatives and Ranking According to Entropy and VIKOR Method}

Decision-makers need to use multi-criteria decision-making tools to help them during the decision-making process. Nowadays, many techniques to solve MCDM problems have been developed. Several evaluation criteria are utilized in Multi-Criteria Decision-Making (MCDM). These comprise of two main groups: MODM (Multi-Objective Decision Making) and MADM (Multi-Attribute Decision Making). MODM is generally used for design and MADM for choosing the best alternatives. The critical difference between MADM and MODM is that MADM is for a continuous and discrete decision-making environment. 
In this section, the algorithm of the decision-making method is presented. The proposed method is based on the weights and rankings of criteria using the Entropy method, and to evaluate supplier's performance using the VIKOR method. VIKOR Technique

VIKOR was developed by Opricovic in 1998 for the first time as one of the multi-criteria decision making (MCDM) or multi-criteria decision analysis methods (Chu et al., 2007) for complex decision making situations with non-commensurable and conflicting criteria. VIKOR recommends a compromise ranking for the decision-maker based on "closeness" to the "ideal" solution. Firstly, this method contains deciding objectives (decision matrix) and then the normalized decision matrix calculations to solve decision problems with conflicting. VIKOR ranks alternatives and determines the solution named compromise that is the closest to the ideal (Opricovic \& Tzeng, 2004). The MCDM problems are declared to Determine the best (compromise) solution in multi-criteria sense from the set of $\mathbf{J}$ feasible alternatives A1, A2, ...AJ, evaluated according to the set of $\mathrm{n}$ criterion functions (Shojaei et al., 2018).

The VIKOR procedure has the following steps:

$>\quad$ Step 1. For each criteria functions, the best $\mathrm{f}^{*}{ }_{i}$ and the worth $\mathrm{f}^{-}{ }_{\mathrm{i}}$ values determination:

$$
\begin{aligned}
& f^{*}{ }_{i}=\max _{i} f_{i j} \\
& f^{*}{ }_{j}=\min _{i} f_{i j} \quad f^{-}{ }_{j}=\min _{i} \text { fij } \\
& \max _{i} \text { fij }
\end{aligned}
$$

and decision matrix determination with $\mathrm{m}$ alternatives and $\mathrm{n}$ criteria as $\mathrm{X}=\mathrm{fij}(\mathrm{Ai}) \mathrm{m} \times \mathrm{n}$.

Step 2. The Si and Ri values calculation with the equations no.3:

$$
\begin{aligned}
S_{i} & =\sum_{j=1} w_{j}\left(f_{j}^{*}-f_{i j}\right) /\left(f_{j}^{*}-f_{j}^{-}\right) \\
R_{i} & =\max _{j}\left[w_{j}\left(f_{j}^{*}-f_{i j}\right) /\left(f_{j}^{*}-f_{j}^{-}\right)\right]
\end{aligned}
$$

$>\quad$ Step 3. The Qi values computation using the equation where:

$\mathrm{S}^{*}=\operatorname{mini} \mathrm{Si}, \mathrm{S}^{*}=\operatorname{mini} \mathrm{Si}$

$\mathrm{R}^{*}=\operatorname{mini} \mathrm{Ri}, \mathrm{R}^{*}=\operatorname{maxi} \mathrm{Ri}$

and $\mathrm{v}$ is introduced as a weigh for the strategy" majority of criteria".

Step 4. The alternatives raking, sorting by the values $S, R$ and $Q$, from the minimum value.

Step 5. Using Q ranking list to propose the compromise solution or set of compromise solutions (Shekhovtsov et al., 2020).

Decision-makers could be accepted the obtained compromise solution because it provides a maximum utility of the majority (represented by min S), and a minimum individual regret of the opponent (represented by min R). The measures 
$\mathrm{S}$ and $\mathrm{R}$ are integrated into $\mathrm{Q}$ for a compromise solution, the base for an agreement established by mutual concessions.

\section{Entropy Weights Method (EWM) Technique}

Entropy use as an uncertainty measurement tool for the system and initially is a thermodynamic subject. EWM provides the disordered degree of a system in information theory and is computed according to the index amount variation (Chou et al., 2012). Shannon and Weaver developed EWM in 1947, and Zeleny developed the concept in 1982. The EWM is used to calculate weights of the attributes and uncertain information calculation through the probability theory to specify the response importance. Firstly, the objectives are decided (decision matrix) by using EWM, and then the normalized decision matrix is calculated. The EWM approach is some benefits as following:

- $\quad$ A simple, uncomplicated, and fairway of weights calculation.

- $\quad$ A successful method to assess the weights of indicators.

- $\quad$ Consistent with contrast intensity and divergence of responses.

- The EWM is a suitable method if the accessible information is inadequate or not.

Provide a quantitative approach of effectiveness and benefit/cost responses and regulate the relationship between several evaluation objects.

- Ignore the effect of some unusual approach and provide the assessment result accurate and sensible.

- $\quad$ Deliver more various coefficient esteems for responses and manage the essential disagreement between the responses in decision-making. (Kumar et al., 2021)

The following steps are applied through the Entropy method for weights measurement: (Kumar et al., 2021).

$>\quad$ Step 1: Objective

Alternatives/experiments are performed with suitable evaluation criteria/responses.

\section{Step 2: Decision Matrix}

The decision format is demonstrated in Eq. (4). Each row is allocated to one experiment and the columns to one response respectively, the eij of the decision template 'DT' [eij; i 1 1/4 1, 2, .., a no. of experiments (n), j 1 1 1 1, 2, .., no. of responses (m)] are contributions for decision format or matrix.

$$
D T=\left[\begin{array}{llllll}
\mathrm{q}_{11} & \mathrm{q}_{12} & -- & \mathrm{q}_{1 j} & -- & \mathrm{q}_{1 \mathrm{~m}} \\
\mathrm{q}_{21} & \mathrm{q}_{22} & -- & \mathrm{q}_{2 j} & -- & \mathrm{q}_{2 \mathrm{~m}} \\
-- & -- & -- & -- & -- & -- \\
\mathrm{q}_{\mathrm{i} 1} & \mathrm{q}_{\mathrm{i} 2} & -- & \mathrm{q}_{\mathrm{ij}} & -- & \mathrm{q}_{\mathrm{im}} \\
-- & -- & -- & -- & -- & -- \\
\mathrm{q}_{\mathrm{n} 1} & \mathrm{q}_{\mathrm{n} 2} & -- & \mathrm{q}_{\mathrm{nj}} & -- & \mathrm{q}_{\mathrm{nm}}
\end{array}\right]
$$




\section{Step 3: Normalization}

To make the dimensionless experimental data of 'DT' (because of several responses part), the linear normalization method is used. For beneficial response, Equation (5) is used (e.g., MRR) and for a non-beneficial reaction (e.g., Ra), Equation (6) is applied. The normalized decision matrix NDM ij $€[0,1]$ :

$$
\begin{aligned}
\operatorname{NDM}_{\mathrm{ij}} & =\frac{q_{i j}}{\operatorname{Maxq_{ij}}}(\text { Beneficial }) \\
\mathrm{NDM}_{\mathrm{ij}} & =\frac{\operatorname{Min}_{\mathrm{ij}}}{q_{i j}}(\text { Non }- \text { beneficial })
\end{aligned}
$$

\section{Step 4: Probability and Entropy}

Equation (7) is used to calculate the response probability (Prij) and Equation (8) is used to obtain the Entropy (Enj) of the jth response.

$$
\begin{aligned}
\mathrm{Pr}_{\mathrm{ij}} & =\frac{\mathrm{NDM}_{\mathrm{ij}}}{\sum_{\mathrm{i}=1}^{\mathrm{n} N D M_{i j}}} \\
\mathrm{En}_{\mathrm{j}} & =-\mathrm{Y} \sum_{\mathrm{i}=1}^{\mathrm{n}} \mathrm{Pr}_{\mathrm{ij}} \log _{\mathrm{e}}\left(\mathrm{Pr}_{\mathrm{ij}}\right)
\end{aligned}
$$

Stable expression is $\mathrm{Y}=\frac{1}{\log _{\mathrm{e}}(\mathrm{n})} \quad(\mathrm{n}:$ No. of experiments and Enj is between zero and one).

\section{Step 5: Divergence and Entropy Weights}

Equation (9) is used to measure the divergence degrees (Divj), and Equation (10) calculates the entropy weight $(\mathrm{Ew})$ of the jth response.

$$
\begin{aligned}
& \operatorname{Div}_{j}=\left|1-\mathrm{En}_{\mathbf{j}}\right| \\
& \mathrm{Ew}_{\mathbf{j}}=\frac{\operatorname{Div}_{j}}{\sum_{j=1}^{\mathrm{m}} \operatorname{Div}_{j}}
\end{aligned}
$$

Recently, researchers implement MCDM and other methods combination to evaluate the performance (Chang et al., 2015). Therefore, this study uses the VIKOR and Entropy method to evaluate the safety performance of flight operations suppliers and rank the priorities of criteria for them accordingly. The relative weight of different evaluation criteria for the supplier's performance comes from the entropy results. We can see that the first two important actors for the performance of suppliers are economic, quality, and safety and reputation respectively. The results show that the first alternative has the best performance.

\section{Case Study of an Airline}

In flight operations, there are some products or services which provided by international or national suppliers. In the light of our literature review conclusion (as Table 1) this paper develops the following criteria and sub-criteria to assess and select supplier (as Table 2). 
Table 2

Criteria and sub Criteria for Flight operations supplier selection

\begin{tabular}{|c|c|c|c|c|c|}
\hline Criteria & Target & Code & Sub Criteria & Ref. & Code \\
\hline \multirow{3}{*}{ Economic } & \multirow{3}{*}{$\begin{array}{l}\text { Minimization } \\
\text { total cost }\end{array}$} & \multirow{3}{*}{$\mathrm{C} 1$} & Best price & $\begin{array}{l}\text { Sar1 et al. } \\
\text { (2016); } \\
\text { Cheng et al. } \\
\text { (2017) }\end{array}$ & $\mathrm{C} 1-1$ \\
\hline & & & $\begin{array}{l}\text { Cost reducing } \\
\text { activities }\end{array}$ & $\begin{array}{l}\text { Sar1 et al. } \\
\text { (2016); } \\
\text { Cheng et al. } \\
\text { (2017) }\end{array}$ & $\mathrm{C} 1-2$ \\
\hline & & & Transportation costs & $\begin{array}{c}\text { Doc } 9859 \\
\text { ICAO, } \\
(2018)\end{array}$ & $\mathrm{C} 1-3$ \\
\hline \multirow{2}{*}{$\begin{array}{c}\text { Delivery } \\
\text { capabilities }\end{array}$} & \multirow{2}{*}{$\begin{array}{c}\text { Minimization } \\
\text { late delivered } \\
\text { items }\end{array}$} & \multirow{2}{*}{$\mathrm{C} 2$} & On-time delivery & $\begin{array}{l}\text { Sar1 et al. } \\
\text { (2016) }\end{array}$ & $\mathrm{C} 2-1$ \\
\hline & & & $\begin{array}{l}\text { Ability to supply } \\
\text { urgent orders }\end{array}$ & $\begin{array}{l}\text { Sar1 et al. } \\
\text { (2016) }\end{array}$ & $\mathrm{C} 2-2$ \\
\hline \multirow{5}{*}{$\begin{array}{l}\text { Quality and } \\
\text { safety }\end{array}$} & \multirow{5}{*}{$\begin{array}{l}\text { Conformity } \\
\text { with mandatory } \\
\text { regulations } \\
\text { (EASA }{ }^{1} \text { and } \\
\text { ICAO } \\
{ }^{2} \text { Standards) }\end{array}$} & \multirow{5}{*}{ C3 } & $\begin{array}{l}\text { Rejected products / } \\
\text { services ratio }\end{array}$ & $\begin{array}{l}\text { Sar1 et al. } \\
\text { (2016) }\end{array}$ & C3-1 \\
\hline & & & $\begin{array}{l}\text { Requirement } \\
\text { fulfillment }\end{array}$ & $\begin{array}{c}\text { Uzan, } \\
(2020) ; \\
\text { Yazdani et } \\
\text { al. (2016); } \\
\text { Shendryk et } \\
\text { al. (2019) }\end{array}$ & C3-2 \\
\hline & & & $\begin{array}{l}\text { Having necessary } \\
\text { documentation }\end{array}$ & $\begin{array}{l}\text { Sar1 et al. } \\
\text { (2016) }\end{array}$ & C3-4 \\
\hline & & & $\begin{array}{l}\text { Neutral and negative } \\
\text { feedback ratio }\end{array}$ & $\begin{array}{l}\text { Uzan, } \\
(2020)\end{array}$ & $\mathrm{C} 3-5$ \\
\hline & & & $\begin{array}{c}\text { Occurrences / Failure } \\
\text { ratio }\end{array}$ & $\begin{array}{l}\text { Shendryk et } \\
\text { al. (2019) }\end{array}$ & C3-6 \\
\hline
\end{tabular}

${ }^{1}$ European Aviation Safety Agency

${ }^{2}$ International Civil Aviation Organization 


\begin{tabular}{|c|c|c|c|c|c|}
\hline Criteria & Target & Code & Sub Criteria & Ref. & Code \\
\hline \multirow{5}{*}{ Service } & \multirow{5}{*}{$\begin{array}{l}\text { Reliability } \\
\text { assurance }\end{array}$} & \multirow{5}{*}{$\mathrm{C} 4$} & $\begin{array}{l}\text { Having adequate } \\
\text { capacity }\end{array}$ & $\begin{array}{c}\text { Ghosh et al. } \\
\text { (2019); } \\
\text { Sar1 et al. } \\
\text { (2016) }\end{array}$ & C4-1 \\
\hline & & & Technical support & $\begin{array}{l}\text { Sar1 et al. } \\
\text { (2016) }\end{array}$ & $\mathrm{C} 4-2$ \\
\hline & & & Innovation proposals & $\begin{array}{l}\text { Sar1 et al. } \\
\text { (2016); } \\
\text { Stević et al. } \\
(2020)\end{array}$ & $\mathrm{C} 4-3$ \\
\hline & & & $\begin{array}{c}\text { Quality } \\
\text { assurance/guarantee } \\
\text { period }\end{array}$ & $\begin{array}{c}\text { Marzouk et } \\
\text { al. (2021); } \\
\text { Wu et al. } \\
(2019)\end{array}$ & C4-4 \\
\hline & & & Quick responsiveness & $\begin{array}{l}\text { Ghosh et al. } \\
\text { (2019) }\end{array}$ & C4-5 \\
\hline \multirow{6}{*}{$\begin{array}{l}\text { Organization } \\
\text { and } \\
\text { management }\end{array}$} & \multirow{6}{*}{$\begin{array}{l}\text { Organizational } \\
\text { improvement }\end{array}$} & \multirow{6}{*}{$\mathrm{C} 5$} & $\begin{array}{l}\text { Preventive and } \\
\text { corrective activities }\end{array}$ & $\begin{array}{l}\text { Stević et al. } \\
\quad(2020)\end{array}$ & C5-1 \\
\hline & & & $\begin{array}{c}\text { Information } \\
\text { disclosure }\end{array}$ & $\begin{array}{l}\text { Sar1 et al. } \\
\text { (2016) }\end{array}$ & $\mathrm{C} 5-2$ \\
\hline & & & $\begin{array}{l}\text { Disciplinary and } \\
\text { security practices }\end{array}$ & $\begin{array}{l}\text { Sar1 et al. } \\
\text { (2016) }\end{array}$ & $\mathrm{C} 5-3$ \\
\hline & & & $\begin{array}{c}\text { Professional \& } \\
\text { Financial competence }\end{array}$ & $\begin{array}{l}\text { Ghosh et al. } \\
\text { (2019); } \\
\text { Stević et al. } \\
(2020)\end{array}$ & $\mathrm{C} 5-4$ \\
\hline & & & $\begin{array}{l}\text { Occupational health } \\
\text { and safety } \\
\text { management system }\end{array}$ & $\begin{array}{l}\text { Marzouk et } \\
\text { al. (2021); } \\
\text { Azadnia et } \\
\text { al. (2012); } \\
\text { Stević et al. } \\
(2020)\end{array}$ & C5-5 \\
\hline & & & R \& D capability & $\begin{array}{l}\text { Wu et al. } \\
\text { (2019) }\end{array}$ & C5-6 \\
\hline
\end{tabular}




\begin{tabular}{|c|c|c|c|c|c|}
\hline Criteria & Target & Code & Sub Criteria & Ref. & Code \\
\hline Reputation & $\begin{array}{c}\text { Proper } \\
\text { international } \\
\text { communication }\end{array}$ & C6 & & $\begin{array}{l}\text { Kumar et al. } \\
(2018) ; \mathrm{Wu} \\
\text { et al. (2019) }\end{array}$ & C6-1 \\
\hline
\end{tabular}

\section{Findings and Discussions}

The supplier selection method is developed in this research by using MCDM method and we conduct the following stages to evaluate suppliers (Flight Crew- Pilot simulator Training):

$\circ$ Firstly, in Table 3, the weight of each criterion is measured according to the ENTROPY model as mentioned previously.

- Secondly, as shown in Table 4, suitable suppliers (Simulator service providers) are selected and assessment results of them categorize by the VIKOR model as mentioned previously.

\section{Table3}

Criteria Comparison for all Criteria Based on the Model

\begin{tabular}{|l|c|c|c|c|c|c|}
\hline & Economic & $\begin{array}{c}\text { Delivery } \\
\text { capabilities }\end{array}$ & $\begin{array}{c}\text { Quality } \\
\text { and } \\
\text { safety }\end{array}$ & Service & $\begin{array}{c}\text { Organization } \\
\text { and } \\
\text { management }\end{array}$ & Reputation \\
\hline Wij & 0.500 & 0.050 & 0.200 & 0.063 & 0.062 & 0.125 \\
\hline supplier 1 & 7 & 9 & 6 & 5 & 7 & 7 \\
\hline supplier 2 & 8 & 7 & 7 & 7 & 5 & 7 \\
\hline supplier 3 & 9 & 7 & 9 & 6 & 7 & 6 \\
\hline supplier 4 & 8 & 6 & 8 & 5 & 5 & 8 \\
\hline
\end{tabular}

The final score for the assessment of each supplier is shown in Table 4:

\section{Table 4}

Suppliers (Simulator Service Providers) Categorization Based on VIKOR Model

\begin{tabular}{|c|c|c|}
\hline Suppliers & Priority & Score \\
\hline Supplier No.01 & 1 & 0.000 \\
\hline Supplier No.02 & 3 & 0.557 \\
\hline Supplier No.03 & 4 & 1.000 \\
\hline Supplier No.04 & 2 & 0.596 \\
\hline
\end{tabular}


The result shows that economic, quality and safety, and reputation respectively are the main criteria to select suppliers. Moreover, the two finance and safety and quality criteria together are the same weight to assess the airline's suppliers. It shows that cost issue is the critical factors for top managers in the aviation industry. Top management in the aviation industry can use the method as a managerial tool (a decision-making aid) to weight criteria and supplier's categorization by organization experts' viewpoints. They are also able to select suppliers and monitor them within the main criteria. In this study, for the first time, main criteria and sub-criteria (to evaluate suppliers) are identified, especially flight operations scope for airline. Moreover, a new decision-making framework is developed to evaluate the performance of suppliers based on the Entropy and VIKOR approaches. However, there is some research (with a focus on the aviation industry), but for IT services suppliers.

\section{Conclusion and Future Research}

In the aviation business environment, using the practical model to establish beneficial safety policies is put on top of all airlines' agendas. This can be used by applying expert viewpoints and categorizing and prioritizing approaches for supplier evaluation. The selection of suppliers is a very critical aspect of SCM. Sustainability in the process of procurement in airline is a strategic issue whose popularity has increased in recent decades. Flight operations is critical activities in airline and their outputs are a direct impact on flight safety consequence. Therefore, the quality of supplier's product and services play the key role in their process.

For supplier selection and evaluation via Entropy and VIKOR method, considering experts' opinions, 6 criteria and 21 sub-criteria are developed. As a case study four suppliers (simulator training for flight crew) are considered and based on VIKOR Technique are evaluated.

This approach can present a model for supplier selection. Of course, due to each organization's experts' viewpoints, this model has the flexibility to adopt some modifications resulting from domestic and environmental parameters. This research cannot justify its generalization to other airlines and other fields of the aviation industry.

The developed model, as a decision-making aid gives an tool to weight criteria and supplier's categorization. By this model, they can monitor suppliers within their main criteria. Based on the rankings and results, the aviation experts were interviewed to verify our results, which confirmed them. The novelty of this paper is the introduction of an integrated model for supplier selection in flight operations.

It is suggested to develop this model by implementing other Fuzzy concepts like Fuzzy Promethee, Electre Promethee (Yatsalo et al., 2021), Electre Fuzzy, Fuzzy Topsis (Akram et al., 2021), and their consolidation to a model related to network analysis to compare and select the most efficient and optimized method. 


\section{Declaration of Conflicting Interests}

The author(s) declared no potential conflicts of interest concerning the research, authorship, and/or publication of this article. 


\section{References}

Akram, M., Ilyas, F., \& Al-Kenani, A. N. (2021). Two-phase group decisionaiding system using ELECTRE III method in Pythagorean fuzzy environment. Arabian Journal for Science and Engineering, 46(4), 35493566.

Azadnia, A. H., Saman, M. Z. M., Wong, K. Y., Ghadimi, P., \& Zakuan, N. (2012). Sustainable supplier selection based on self-organizing map neural network and multi-criteria decision-making approach. Procedia-Social and Behavioral Sciences, 65, 879-884.

Chang Y. H., Shao, P. C., \& Chen, H. J. (2015). Performance evaluation of airport safety management systems in Taiwan. Safety Science, 1(75), 72-86.

Cheng, Y., Peng, J., Zhou, Z., Gu, X., \& Liu, W. (2017). A hybrid DEA-Adaboost model in supplier selection for fuzzy variables and multiple objectives. IFAC-PapersOnLine, 50(1), 12255-12260.

Chou, Y. C., Yen, H. Y., \& Sun, C. C. (2014). An integrated method for performance of women in science and technology-based on entropy measure for objective weighting. Quality \& Quantity, 48(1), 157-72.

Chu, M. T., Shyu, J., Tzeng, G. H., \& Khosla, R. (2007). Comparison among three analytical methods for knowledge communities group-decision analysis. Expert Systems with Applications, 33(4), 1011e1024.

ICAO. (2013). Annex 19 safety management (1st ed.). Author.

Feng, B., Fan, Z. P., \& Li, Y. (2011). A decision method for supplier selection in multi-service outsourcing. International Journal of Production Economics, 132(2), 240-250.

Ghosh, S. K., Zoha, N., \& Sarwar, F. (2019). A generic MCDM model for supplier selection for multiple decision makers using fuzzy TOPSIS. Proceedings of the 5th International Conference on Engineering Research, Innovation and Education.

Hashmi, N., Jalil, S. A., \& Javaid, S. (2021). Carbon footprint-based multiobjective supplier selection problem with uncertain parameters and fuzzy linguistic preferences. Sustainable Operations and Computers, 2, 20-29.

Hendiani, S., Mahmoudi, A., \& Liao, H. (2020). A multi-stage multi-criteria hierarchical decision-making approach for sustainable supplier selection. Applied Soft Computing, 94, 106456.

Ho, W., Xu, X., \& Dey, P. K. (2010). Multi-criteria decision-making approaches for supplier evaluation and selection: A literature review. European Journal of Operational Research, 202(1), 16-24.

Kumar, S., Kumar, S., \& Barman, A. G. (2018). Supplier selection using fuzzy TOPSIS multi-criteria model for a small-scale steel manufacturing unit. Procedia Computer Science, 133, 905-912. 
Kumar, R., Singh, S., Bilga, P. S., Jatin, K., Singh, J., Singh, S., Scutaru, M. L., \& Pruncu, C. I. (2021). Revealing the benefits of entropy weights method for multi-objective optimization in machining operations: A critical review. Journal of Materials Research and Technology.

Lam, W. S., Lam, W. H., Jaaman, S. H., \& Liew, K. F. (2021). Performance evaluation of construction companies using integrated entropy-fuzzy VIKOR model. Entropy, 23(3), 320.

Marzouk, M., \& Sabbah, M. (2021). AHP-TOPSIS social sustainability approach for selecting a supplier in the construction supply chain. Cleaner Environmental Systems, 2, 100034.

Petrović, G., Mihajlović, J., Ćojbašić, Ž., Madić, M., \& Marinković, D. (2019). Comparison of three fuzzy MCDM methods for solving the supplier selection problem. Facta Universities, Series: Mechanical Engineering, 17(3), 455-469.

Sarı, T., Baynal, K., \& Ergul, O. (2016). Supplier selection with grey relational analysis. International Journal of Emerging Research in Management \& Technology, 5, 61-70.

Opricovic, S. (1998). Multicriteria optimization in civil engineering (in Serbian)(Faculty of Civil Engineering, Belgrade. ISBN 86-80049-82-4.

Opricovic, S., \& Tzeng, G.-H. (2004). The compromise solution by MCDM methods: A comparative analysis of VIKOR and TOPSIS. European Journal of Operational Research, 156(2), 445-455.

Shendryk, V., Bychko, D., Parfenenko, Y., Boiko, O., \& Ivashova, N. (2019). Information system for selecting the supplier of the optimal goods. Procedia Computer Science, 149, 57-64.

Shekhovtsov, A., \& Sałabun, W. (2020). A comparative case study of the VIKOR and TOPSIS rankings similarity. Procedia Computer Science, 1(176), 3730-40.

Shojaei, P., Haeri, S. A., \& Mohammadi, S.(2018). Airports evaluation and ranking model using Taguchi loss function, best-worst method, and VIKOR technique. Journal of Air Transport Management, 1(68),4-13.

Stević, Ž., Pamučar, D., Puška, A., \& Chatterjee, P. (2020). Sustainable supplier selection in healthcare industries using a new MCDM method: Measurement of alternatives and ranking according to Compromise solution (MARCOS). Computers \& Industrial Engineering, 140, 106231.

Uzan, S. B. (2020). Analysis of supplier selection process with multi-criteria decision making techniques; Example of an airline. Journal of Economics and Administrative Sciences, 34(2), 315-334.

Wu, Y., Ke, Y., Xu, C., \& Li, L. (2019). An integrated decision-making model for sustainable photovoltaic module supplier selection based on the combined weight and cumulative prospect theory. Energy, 181, 1235-1251. 
Yazdani, M., Hashemkhani Zolfani, S., \& Zavadskas, E. K. (2016). New integration of MCDM methods and QFD in the selection of green suppliers. Journal of Business Economics and Management, 17(6), 10971113.

Yatsalo, B., Korobov, A., Öztayşi, B., Kahraman, C., \& Martínez, L. (2021). Fuzzy extensions of PROMETHEE: Models of different complexity with different ranking methods and their comparison. Fuzzy Sets and Systems, 422, 1-26. 